\title{
An Investigation of the Relationship between Autonomous Learning and Lifelong Learning
}

\author{
Cengiz YURDAKUL ${ }^{1}$
}

\begin{tabular}{l} 
ARTICLE INFO \\
\hline Article History: \\
Received 08.08.2016 \\
Received in revised form \\
15.12.2016 \\
Accepted \\
Available online 01.01 .2017
\end{tabular}

\begin{abstract}
The present study aims to investigate the relationship between autonomous learning and lifelong learning. The study group consists of 657 secondary school students enrolled in three public schools, aged $11-16$ from Sakarya, Turkey. In this study, relationships between the variables of autonomous learning and lifelong learning and the sub-dimensions of autonomous learning were investigated. Pearson Product Moment Correlation, Partial Correlation methods were utilized in order to investigate these relationships. Autonomous Learning Scale (12 items) which was developed by Macaskill and Taylor (2010), was adapted to Turkish by Arslan and Yurdakul (2015) was conducted to measure autonomous learning. Lifelong Learning Scale (14 items) which was developed by Kirby, Knapper, Lamon and Egnatoff (2010), was adapted to Turkish by Arslan and Akcaalan (2015) was carried out to assess lifelong learning level. In the light of the research findings, it can be purported that autonomous learning and lifelong learning scores were correlating significantly. According to the existing results, it can be argued that autonomous learning which can be defined as the capacity to take charge of one's own learning, has a positive interaction with lifelong learning which can be found voice in one's ongoing, voluntary, and self-motivated learning.
\end{abstract}

C 2017 IJERE. All rights reserved

Keywords:

Autonomous Learning, Lifelong Learning, Demographic Variables.

\section{INTRODUCTION}

\section{Autonomous Learning}

Over the last two decades, the responsibility for learning has shifted from the teacher to the learner with the help of learner autonomy and learner empowerment $(\mathrm{Ng}$, Confessore, Abdullah, 2012). While "autonomy" is about people taking more control over their lives individually and collectively, "autonomy in learning" is about people taking more control over their learning both inside and outside classrooms (Benson, 2001). According to Chene (1983), autonomy is a structure which makes possible the appropriation of learning by the learner whose independence and the will to learn constitute autonomy of the learner. For their own learning, autonomous learners are able to take responsibility (Littlewood, 1999). Benson (2001) emphasizes that autonomy is an attribute of the learner's approach to learning rather than a method of teaching or learning.

In the process of autonomous learning, the learner makes an intentional decision to assume the responsibility for goal setting, planning, and action in a learning situation (Derrick, 2001). In other words, the learner is in control of the learning. Littlewood (1999) defined autonomous learning as "involving students' capacity to use their learning independently of teachers," and "a capacity to communicate autonomously". Holec (1980) defines autonomous learning as "the capacity to take charge of one's own learning". Thus, learner autonomy is a capacity, attribute, and attitude (Holec, 1980; Little, 1991), and can take different forms in different contexts, and to different degrees as a result of the characteristics of each learner. In other words, it is a matter of degree (Nunan, 1997).

Social actions constitute the concept of autonomy to improve the "quality of life" developing one's ability to act more responsibly in running the affairs of the society (Holec, 1980). This concept was developed within four conative factors that would help them to effectively navigate through the educational process: desire, resourcefulness, initiative, and persistence. These factors were recognized as conative, or intentional, factors because each is based on the psychological characteristics of an individual to engage in autonomous learning (Derrick, 2001). Carr (1999), Derrick (2001), Meyer (2001), and Ponton (1999) identified that autonomous learning is actually a behavioral syndrome that consists of four conative factors: desire to learn, learner

${ }^{1}$ Corresponding e-mail: cengizyurdakul@hotmail.com 
resourcefulness, learner initiative, and learner persistence. Similarly, autonomous learning was defined as the exhibition of desire, resourcefulness, initiative, and persistence in learning, and in another definition it was defined as the "manifestation of the behaviors associated with resourcefulness, initiative, and persistence in learning" (Derrick, Ponton, Carr, Rovai and Coe, 2007). There are many individual traits of learner autonomy such as desire, self-efficacy, and curiosity that affect the development of autonomous learning (Derrick et al., 2007). It was also identified as "the characteristic of the person who independently exhibits agency in learning activities" (Ponton, 1999).

\section{Lifelong Learning}

The idea of lifelong learning is not new. The concept of lifelong learning was introduced in the 1960s. In the 1970s, international organizations such as UNESCO adopted the concept of lifelong learning. However, there was little focus on lifelong learning from the 1970s to the 1990s. In the 1990s, the impact of globalization, the effects of an aging society, and the influence of information technology emerged from obscurity (Chang, Wu and Lin, 2012). Therefore, many countries started to focus on lifelong learning in 1990s, and new regulations were introduced to guarantee its implementation (Jarvis 2007; Kang 2007). The importance of implementing lifelong learning is to eliminate a gap in access to education within the community and to provide more equitable access to educational resources (Williamson 1998).

Reframing policy to enhance lifelong learning is an effective approach in a democratic society (Nerland 2008). In many countries, the purpose of lifelong learning policies is to eliminate the unequal distribution of educational attainment, which might result in intellectual, social and economic inequalities. According to Candy (1991), "Lifelong learning takes, as one of its principal aims, equipping people with skills and competencies required to continue their own "self-education" beyond the end of formal schooling". So, it is critical for today's people because of the fast-changing nature of information age. In the information age, the knowledge and competencies are becoming major components of competition between countries, business companies, and individuals. People need to learn across the lifespan in order to adapt to the changing nature of the information age. Therefore, lifelong learning has to impact on the learners' lives, change their mindsets (Fischer, 1999).

Work environments of the 21st Century place people in an information-rich world. New technologies and new information come to people every day. People need to deal with the changing environment in order to catch up the gap between the school and the workplace. The traditional division of a lifetime is not appropriate for the current and the future education of people. The current education units still are lecture dominated and curriculum-dominated. They do not facilitate cultivating the students to learn the learning skill in their future lives. Therefore, McCombs (1991) suggested that the formal education environment should also promote the lifelong learning, as well as the formal education purposes.

Consequently, globalization has created the need for students, workers, and adults to "learn how to learn" individually and collectively. In this postmodern information society, it has been estimated that the amount of information in the world doubles every few years. Some speculate that "half of what professionals know when they finish their formal training will be outdated in less than five years, perhaps even months for those in technology-related careers" (Merriam and Caffarella, 1999). As Fischer (2000) said, "Lifelong learning is more than training". People need to learn by themselves in order to adapt to new environment after training. To this end, education processes in formal and non-formal learning environments must seek to develop attitudes that foster the development of autonomous lifelong learners.

\section{METHOD}

In this study, relationships between the variables of autonomous learning and lifelong learning and the sub-dimensions of autonomous learning were investigated. Pearson Product Moment Correlation, Partial Correlation methods were utilized in order to investigate these relationships. Moreover, descriptive statistics such as mean, standard deviation and percentile values were calculated. The study group consists of 657 secondary school students enrolled in three public schools named İstiklal Secondary School, Sabihahanım 
Secondary School and Osmanbey Secondary School, aged 11 - 16 from Sakarya, Turkey. Demographic features of the participants are demonstrated in Table 1 and Figure 1.

Table 1. Demographic Features of the Participants

\begin{tabular}{ccc}
\hline Variable & Number & Percentage \\
\hline Gender & & \\
\hline Male & 285 & 43.4 \\
Female & 372 & 56.6 \\
\hline Grade & & \\
\hline $6^{\text {th }}$ Grade & 207 & 31.5 \\
$7^{\text {th }}$ Grade & 205 & 31.2 \\
$8^{\text {th }}$ Grade & 245 & 37.3 \\
\hline Total & 657 & 100
\end{tabular}

\section{GENDER}

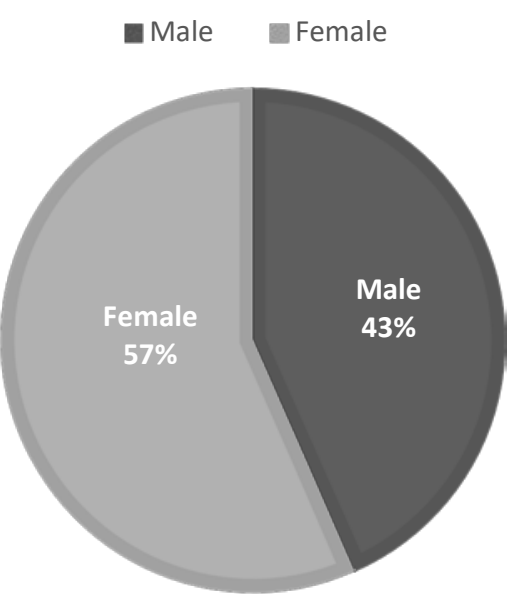

GRADE

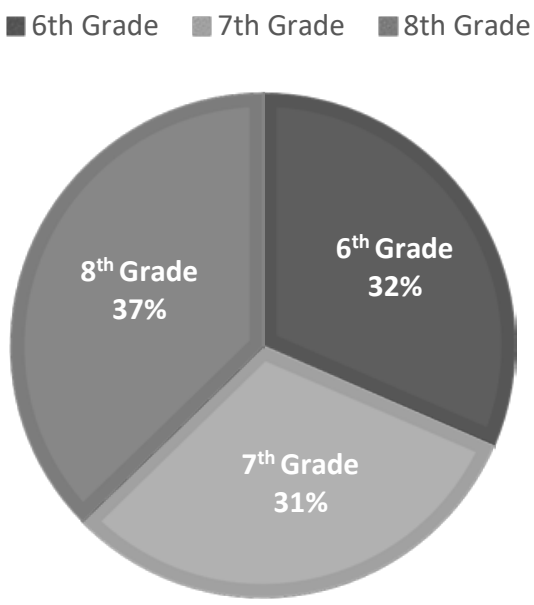

Figure 1. Demographic Features of the Participants as Pie Charts

As seen from the Table 1. and Figure 1., 285 participants were male which constituted $43 \%$ of the sample and 372 participants were female which constituted $57 \%$ of the sample. 207 students were at the sixth grade, which constituted $32 \%$ of the sample, 205 students were at the seventh grade, which constituted $31 \%$ of the sample, and 245 students were at the eighth grade, which constituted $37 \%$ of the sample.

\section{Material}

Autonomous Learning Scale (12 items) which was developed by Macaskill and Taylor (2010), was adapted to Turkish by Arslan and Yurdakul (2015) was conducted to measure autonomous learning. Lifelong Learning Scale (14 items) which was developed by Kirby, Knapper, Lamon and Egnatoff (2010), was adapted to Turkish by Arslan and Akcaalan (2015) was carried out to assess lifelong learning level. Demographic information of the students were obtained from a personal information form including 3 personal questions.

The results of confirmatory factor analysis for Autonomous Learning Scale (Turkish Version) described that the 12 items loaded two factors and the two dimensional model was well fit $\left(x^{2}=207.03, d f=53\right.$, RMSEA=.062, GFI=.96, CFI=.96, IFI=.96, AGFI=0.94, RFI=.93, NNFI=.95, NFI=.94, and SRMR=.044). The 
internal consistency coefficient was .80 for the overall scale. The item-total correlations of ALS ranged from .29 to .59 (Arslan and Yurdakul, 2015).

The results of confirmatory factor analysis for Lifelong Learning Scale (Turkish Version) described that the 14 items loaded one factor and the unidimensional model was well fit $\left(x^{2}=206.39, \mathrm{df}=53, \mathrm{RMSEA}=.070\right.$, $\mathrm{GFI}=.94, \mathrm{CFI}=.89, \mathrm{IFI}=.89$, AGFI= 0.92 and $\mathrm{SRMR}=.059$ ). The internal consistency coefficient was .67 for the overall scale. The corrected item-total correlations of LLS ranged from .18 to .49 (Arslan and Akcaalan, 2015).

\section{Data Analyses}

In each stages of the data analyses, SPSS 22.00 statistical package program was utilized. Pearson Product Moment Correlation and Partial Correlation methods were carried out. The differences on the levels of autonomous learning and lifelong learning in terms of gender and class level variables were examined with the statistical procedures of independent samples t-test for variables having two groups and One-Way Analysis of Variance (ANOVA) for variables having more than two groups. Tukey's Multiple Comparison Test was utilized so as to figure out which pair of groups had statistically significant differences. Moreover, descriptive statistics such as mean, standard deviation and percentile values were calculated.

\section{FINDINGS}

Pearson Product Moment Correlation Analyse which was carried out in order to determine the relationship between autonomous learning and lifelong learning levels of the secondary school students, demonstrating magnitude and directions of the relationship, was shown in Table 2.

Table 2. Correlation Analysis Results of Relationship between Independence of Learning, Study Habits and Lifelong Learning Levels of Secondary School Students

\begin{tabular}{llll}
\hline & IL & SH & LLL \\
\hline 1. IL & 1 & & \\
2. SH & $.64^{* *}$ & 1 & \\
3. LLL & $.28^{* *}$ & $.32^{* *}$ & 1 \\
\hline Mean & 27.1 & 19.1 & 44.4 \\
Standart Deviation & 4.3 & 3.7 & 3.5 \\
\hline Note: IL= Independence of Learning, SH= Study Habits, LLL= Lifelong Learning Level \\
\multicolumn{4}{l}{} \\
& $* *$ p $<.001$ & \\
\end{tabular}

As shown in Table 2., there is significant relationship between secondary school students' independence of learning, study habits and lifelong learning level. Table 2. demonstrates that there is a positive direction relationship between "lifelong learning" and "independence of learning" $(r=.28, p<.001)$, between "lifelong learning" and "study habits" ( $r=.32, p<.001)$.

\section{CONCLUSION}

The relationship between autonomous learning and lifelong learning and whether there are differences on the levels of two constructs in terms of gender and class level were investigated in this research study. In the light of the research findings, it can be purported that autonomous learning and lifelong learning scores were correlating significantly. Independence of learning and study habits which are the sub-dimensions of autonomous learning were predicting lifelong learning positively. According to the existing results, it can be asserted that autonomous learning which can be defined as the capacity to take charge of one's own learning, has a positive interaction with lifelong learning which can be found voice in one's ongoing, voluntary, and self-motivated learning (Yurdakul, 2016). Both for autonomous learning and lifelong learning, there were significant gender differences in female students' favour. There were also significant 
class level differences on autonomous learning. On the other hand, there were no significant class level differences on lifelong learning.

\section{REFERENCES}

Arslan, S., \& Akcaalan, M. (2015). The adaptation and validation of the Turkish version of the lifelong learning scale (LLS). The Journal Of International Educational Science, Issue, 4, 449-455.

Arslan, S., \& Yurdakul, C. (2015). Turkish adaptation and validation of autonomous learning scale. Journal of International Social Research, 8(39), 565-569.

Benson, P. (2001). Teaching and researching autonomy in language learning. Harlow, UK: Longman.

Candy, P. C. (1991). Self-direction for lifelong learning. A comprehensive guide to theory and practice. San Francisco CA: Jossey-Bass, 94104-1310.

Carr, P. B. (1999). The measurement of resourcefulness intentions in the adult autonomous learner. Unpublished Ph. D dissertation, The George Washington University.

Chang, D. F., Wu, M. L., \& Lin, S. P. (2012). Adults engaged in lifelong learning in Taiwan: Analysis by gender and socioeconomic status. Australian Journal of Adult Learning, 52(2), 310.

Chene, A. (1983). The concept of autonomy: A Philosophical Discussion. Adult Education Quarterly, 34, 38-47.

Derrick, M. G. (2001). The measurement of an adult's intention to exhibit persistence in autonomous learning. (Doctoral Dissertation. The George Washington University, 2001). Dissertation Abstracts International, 62(05), 2533B.

Derrick, M. G., Ponton, M. K., Carr, P. B., Rovai, A. P., \& Coe, J. G. (2007). Review of the finding on the relationship of curiosity and autonomous learning. Paper Presented at the 21st International SelfDirected Learning Symposium, Cocoa Beach, FL.

Fischer, G. (1999). Lifelong learning: Changing mindsets. In 7th International Conference on Computers in Education on" New Human Abilities for the Networked Society"(ICCE'99, Chiba, Japan), IOS Press, Omaha (pp. 21-30).

Fischer, G. (2000). Lifelong learning-more than training. Journal of Interactive Learning Research, 11(3), 265.

Holec, H. (1980). Autonomy and foreign language learning. Strasbourg: Council of Europe.

Jarvis, P (2007). Globalization, lifelong learning and the learning society: Sociological perspectives. London: Routledge.

Kang, DJ (2007). Rhizoactivity: Toward a postmodern theory of lifelong learning. Adult Education Quarterly, 57(3): 205-220.

Kirby, J. R., Knapper, C., Lamon, P., \&Egnatoff, W. J. (2010). Development of a scale to measure lifelong learning. International Journal Of Lifelong Education, 29(3), 291-302.

Little, D. (1991). Learner autonomy 1: Definitions, issues and problems. Dublin: Authentik Language Learning Resources Ltd.

Littlewood, W. (1999). Defining and developing autonomy in east asian contexts. Applied Linguistics, 20(1), 71-94.

Macaskill, A., \& Taylor, E. (2010). The development of a brief measure of learner autonomy in university students. Studies in Higher Education, 35(3), 351-361.

McCombs, B. L. (1991). Motivation and life-long learning. Educational Psychologist, 26(2), 117-127.

Merriam, S. B., \&and Caffarella, R. S. (1999). Learning in adulthood: A comprehensive guide (2nd ed.). San Francisco: Jossey-Bass. 
Meyer, D. A. (2001). The measurement of intentional behavior as a prerequisite to autonomous learning (Doctoral Dissertation, The George Washington University, 2001). Dissertation Abstracts International, 61, 4697.

Nerland, M. (2008). Knowledge cultures and the shaping of work-based learning: The case of computer engineering. Vocations and Learning, 1(1), 49-69.

Nunan, D. (1997). Designing and adapting materials to encourage learner autonomy. In P. Benson \& P. Voller (Eds.), Autonomy and Independence in Language Learning (pp.192-203). New York: Addison Wesley Longman.

Ponton, M. K. (1999). The measurement of an adult's intention to exhibit personal initiative in autonomous learning. (Doctoral Dissertation, The George Washington University, 1999). Dissertation Abstracts International, 60, 3933.

Siew Foen Ng, Gary J. Confessore, Moniza Abdullah, (2012). Learner autonomy coaching: enhancing learning and academic success. International Journal of Mentoring and Coaching in Education, 1 (3), 191 $-204$

Williamson, B. (1998). Lifeworlds and learning. Essays in the theory, philosophy and practice of lifelong learning. Leichester: NIACE.

Yurdakul, C. (2016). Özerk öğrenme ve yaşam boyu öğrenme arasındaki ilişkinin incelenmesi. Yüksek Lisans Tezi. Sakarya Üniversitesi, Eğitim Bilimleri Enstitüsü. 